\title{
Downstream coarsening of subsurface sediment grain size along upper Prahova River (Romania)
}

\author{
Daniela Elena GOGOAȘE NISTORAN ${ }^{1}$, Livioara BRAŞOVANU ${ }^{2}$, \\ Cristina Sorana IONESCU ${ }^{1}$, Iuliana ARMAȘ ${ }^{2}$ \\ ${ }^{1}$ University Politehnica of Bucharest, Faculty of Power Engineering, Romania, \\ ${ }^{2}$ University of Bucharest, Faculty of Geography, Romania \\ dnistoran@gmail.com
}

\begin{abstract}
The paper presents the results obtained from a subsurface sediment grain size analysis along the upper, gravel-bed, Prahova River, Romania. Samples were taken from 20 locations over a $56 \mathrm{~km}$ study reach and were subsequently sieved and weighted in the laboratory. Both $\mathrm{d}_{50}$ and $\mathrm{d}_{84}$ characteristic diameters were plotted against distance and an overall downstream coarsening was identified. Considering the natural and anthropic context of the studied reach, hypotheses to explain this trend were launched.
\end{abstract}

Keywords: sediment grading curve, mean diameter, sieve analysis, volumetric analysis, gravel-bed river, $d_{50}, d_{84}$, downstream coarsening, downstream fining

\section{INTRODUCTION}

The analysis of river sediment patterns provides valuable information about the interrelationships between the control and response variables that influence river channel changes (Armas et al., 2012; Rădoane et al., 2008, Dumitriu et al., 2011; Rădoane et al., 2002).

On the one hand, natural control variables (such as: climate, geology, lithology, topography, soil cover, slope processes, land use, tributaries) act at the macroscale catchment context and determine long-term liquid and solid fluxes into the river channel.

On the other hand, anthropic control variables (such as: channel works, river regulation, road/railway construction, land use, deforestation / afforestation, channel gravel mining, small-hydropower plants) induce a shorter-term geomorphic adjustment of river morphodynamics.

Response variables that characterise channel morphology include: channel planform, bed slope, bankfull width and depth, meandering and braiding indexes, and sediment size distribution and sorting.

In this context, knowledge on particle-size variation along a riverbed is necessary in order to understand the complexity of the interrelated physical stream processes such as hydrodynamics and sediment transport against the background of human impact.

In gravel-bed river reaches with fine sediment supply from upstream and/or tributaries, a downstream fining of sediment bed material is a common phenomenon. This is mainly due to slope reduction in the flow direction, which decreases bed-load sediment transport rates and leads to a combination of particle abrasion, wear and selective transport (Shumm et al., 1973; Fergusson et al., 1996).

Several researchers (Surian, 2002; Brummer et al., 2003; Sear, 1992; Gibson, 2016; Dumitriu et al., 2011) stated that a reverse tendency of downstream coarsening of bed material may appear due to major tributary coarse sediment input, downstream dams (Veicat, 2006) and where the flows are substantially regulated.

The upper section of Prahova River passes through an area that has the highest population density in the Subcarpathians. Consequently, the anthropogenic impact upon the river has been extremely intense, especially over the past 200 years (Ioana-Toroimac, 2015; Armaș, 2012; Braşovanu, 2017). 
The purpose of this study is to analyse the variability of sediment particle size from the subsurface layer along a $56 \mathrm{~km}$ reach of the upper Prahova River, through sieve analysis. Correlations between the natural and man-made impacts and particle size variability are analysed and explanatory hypotheses are then proposed.

\section{STUDY AREA}

Prahova River is a second order tributary of the Danube River, located in the central-southern part of Romania. Its source is situated in local administrative unit Predeal, in the Carpathian
Mountains, (1037 $\mathrm{m}$ above sea level), and its mouth is at Patru Frați (63 m a.s.l.), where it joins Ialomița River. Its total length and watershed area are $190 \mathrm{~km}$ and $3750 \mathrm{~km}^{2}$, respectively (Fig. 1). The mean annual flow rate at its mouth is $27 \mathrm{~m}^{3} / \mathrm{s}$ (Brașovanu, 2018).

The upper Prahova River, considered from the source to the confluence with its tributary Doftana, passes through the Carpathian and Subcarpathian reaches (Fig. 1). It has a length of about $56 \mathrm{~km}$ and a difference in altitude of $2140 \mathrm{~m}$. The corresponding channel slopes over these reaches are 12.5 and 11.7 $\mathrm{m} / \mathrm{km}$, respectively. The narrow watershed has a non-symmetrical shape and the two reaches are linked by the Posada Defile (Fig. 1).

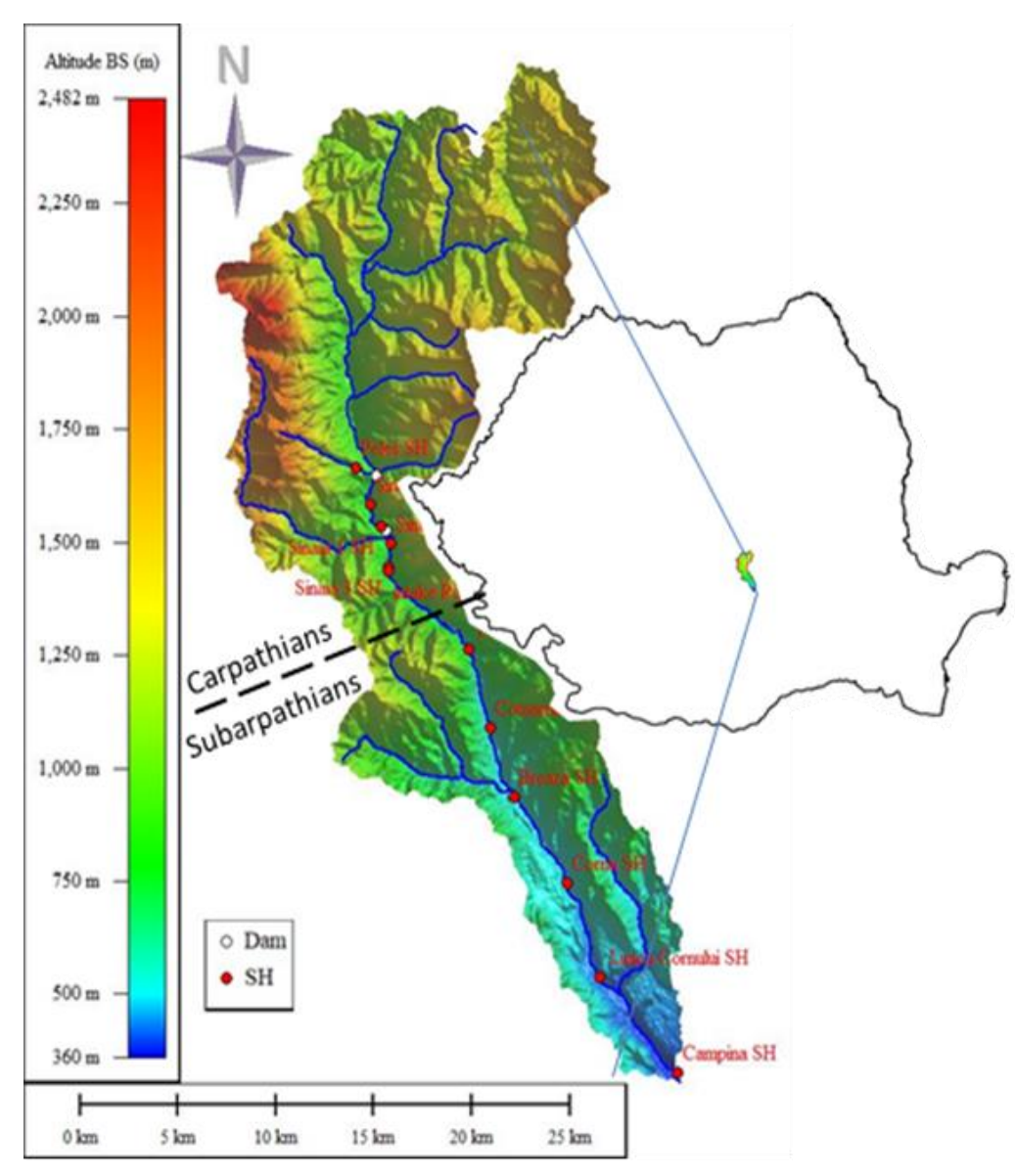

Figure 1 The study reach of upper Prahova River (SH - Small Hydropower plant)

Over the last 200 years, the area has been greatly impacted by anthropic activities such as: construction of railway, roads and bridges, channel regulation and bank protection works, gravel mining, building of two small dams and 10 run-ofriver hydropower plants, afforestation/deforestation, oil exploitation, population growth and tourism
(Braşovanu, 2017; Armaș et al., 2012; Dobre, 2009).

All the aforementioned factors induced important modifications in the morphology of the river channel, affecting both the longitudinal profile and planform. These alterations consisted of pronounced bed incision (up to 3-4 $\mathrm{m}$ in some 
locations), channel narrowing and a transition from braiding to a mixture of braiding and sinuous, single-thread planform patterns (Armaş, 2012; Ioana-Toroimac, 2014; Leopold et al., 1964).

Mean annual flows at Bușteni and Câmpina gauging stations are 4.9 and $8.15 \mathrm{~m}^{3} / \mathrm{s}$. Over the past decades, an increasing number of high intensity flood events were recorded in the study reach.

The mean annual suspended sediment flow, at Câmpina Gauging Station (at the downstream end of the study reach), shows a decreasing trend over the past 50 years, from 15 to $9 \mathrm{~kg} / \mathrm{s}$ (Braşovanu, 2017). A similar trend was documented for minimum and maximum annual sediment flows (Braşovanu, 2017).

\section{METHOD}

Field surveys were conducted during the autumn of 2017 to gather sediment samples in 20 locations along the upper reach of Prahova River. The locations were selected in the proximity of the water, on the exposed side or mid-channel bars (Bunte, 2001; Radoane et al., 2006, Hedrick et al., 2013), which were placed at a mean relative distance of about $3 \mathrm{~km}$ (Fig. 2). From the sampling area of approximately $1 \mathrm{~m}^{2}$, the surface layer was removed at a depth equal to the largest particle diameter. Samples from the surface layer are analysed in another paper (Gogoașe Nistoran et al., 2019).

For each location, finer particles from the subsurface layer were collected into a large bucket and mixed thoroughly. A representative smaller sample was then extracted into a box, which was subsequently oven-dried and then sieved and weighted.

Nine standard sieves (according to ISO 33101/2016 standard) were used to perform the standard grain size analysis of the samples in the laboratory.

\section{RESULTS AND DISCUSSIONS}

Particle size distribution curves were derived for all sampling locations (Fig. 3 a to d). Characteristic diameters $d_{50}$ and $d_{84}$ were identified using the calculator provided by Gary Parker (2004). One can see the mean diameters, $d_{50}$, fall within the range 2-8 $\mathrm{mm}$ (with an average value of $5 \mathrm{~mm}$, specific to fine gravels), whereas $d_{84}$ fall within the range 4-13 $\mathrm{mm}$ (with an average value of $11 \mathrm{~mm}$, specific to medium gravels).

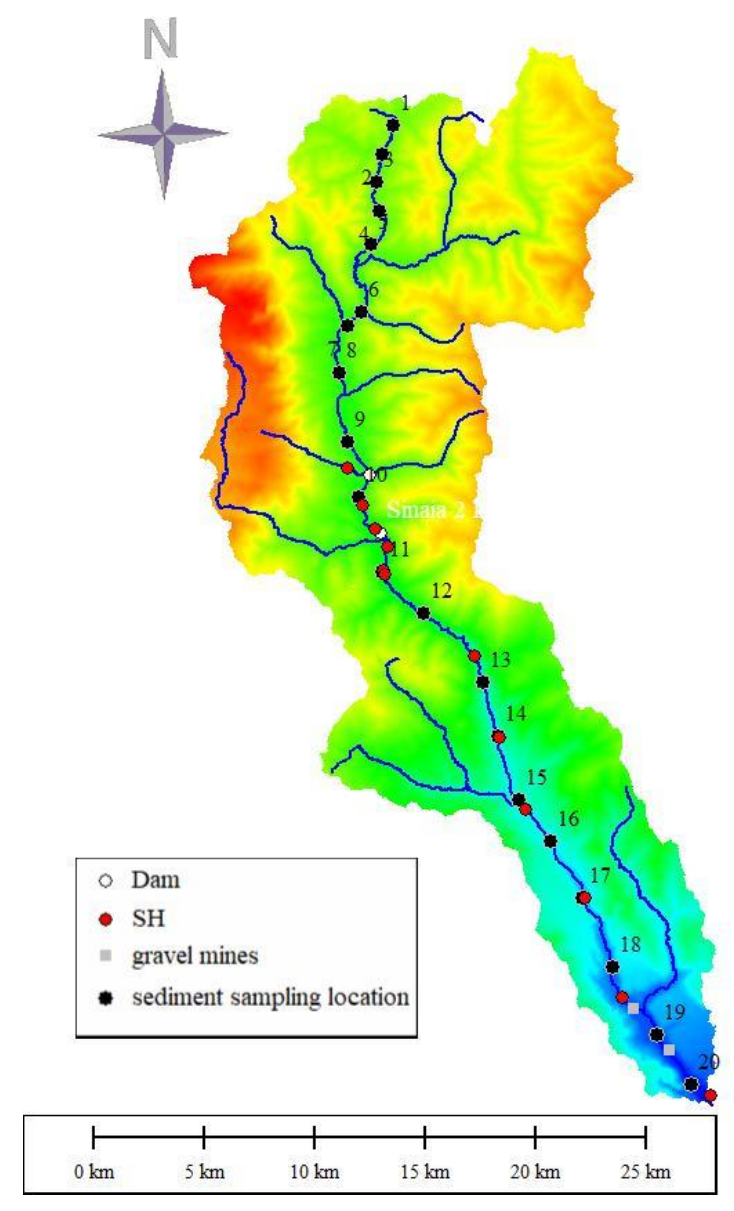

Figure 2 Sediment sampling locations along upper Prahova River reach

The resulting diameters were plotted against distance from river source in Fig. 4 and Fig. 5. Sample no. 1 was removed from the plots since it was the only one taken from the riverbed, below the water surface, consisting of a mixture of particles from both surface and subsurface layers.

Diameters show an overall increasing trend with distance, which is consistent with the downstream coarsening phenomenon documented by other authors for gravel-bed rivers (Brummer and Montgomery, 2003; Gibson et al., 2016; Dumitriu, 2011).

According to various authors, downstream coarsening is usually localized, due to coarse material supplied by tributaries, debris flows 
(Brummer and Montgomery, 2003) or high energy currents (Solari and Parker, 2000).

This specific feature identified along the upper Prahova River could be explained by the following natural factors: morphometric characteristics of this

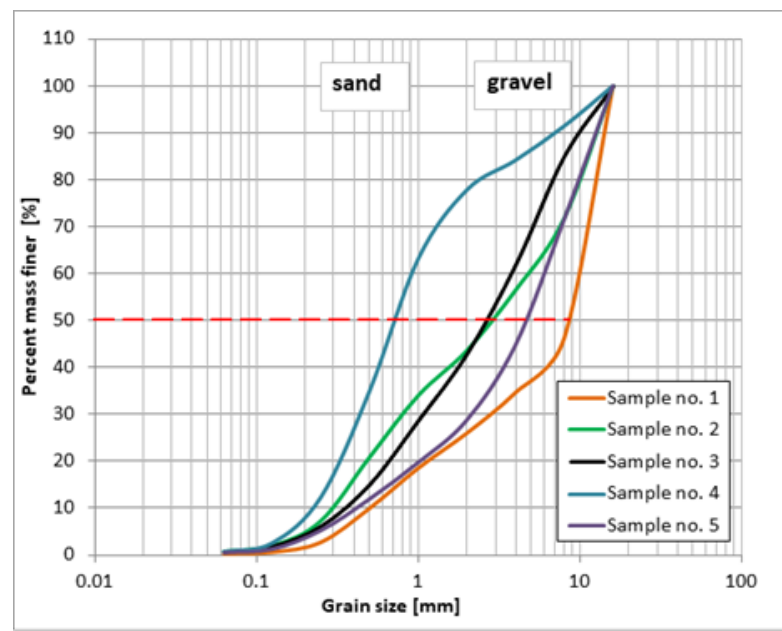

a)

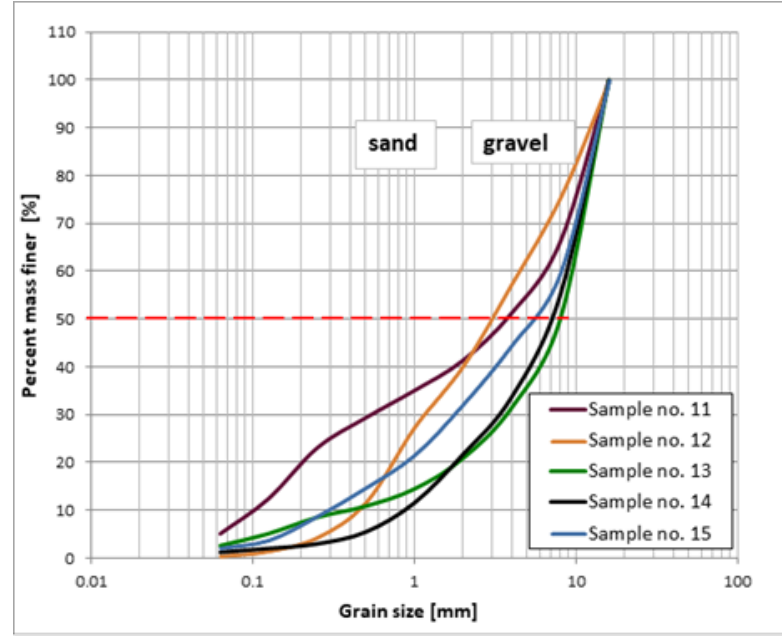

c) sediment production zone (steep hillslopes, narrowelongated watershed) coupled with destructive flash floods produced by high intensity rainfall events and scarce vegetation on high altitude areas.

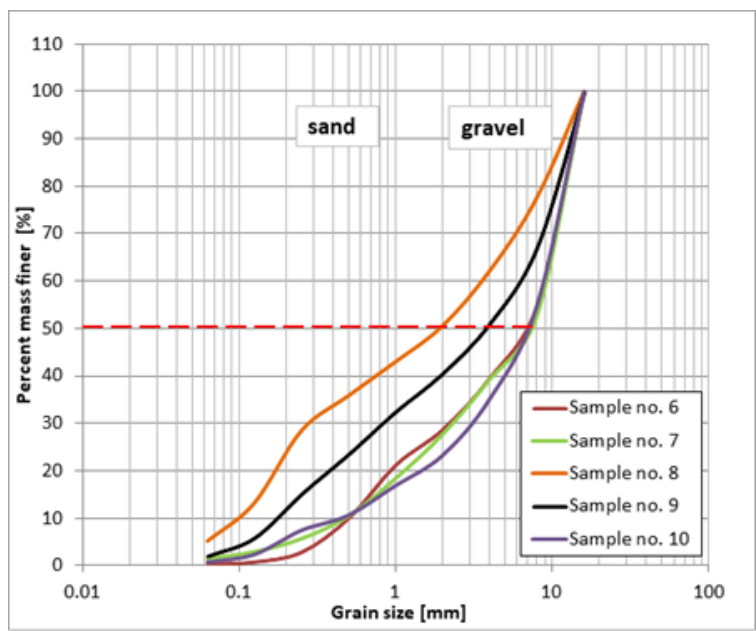

b)

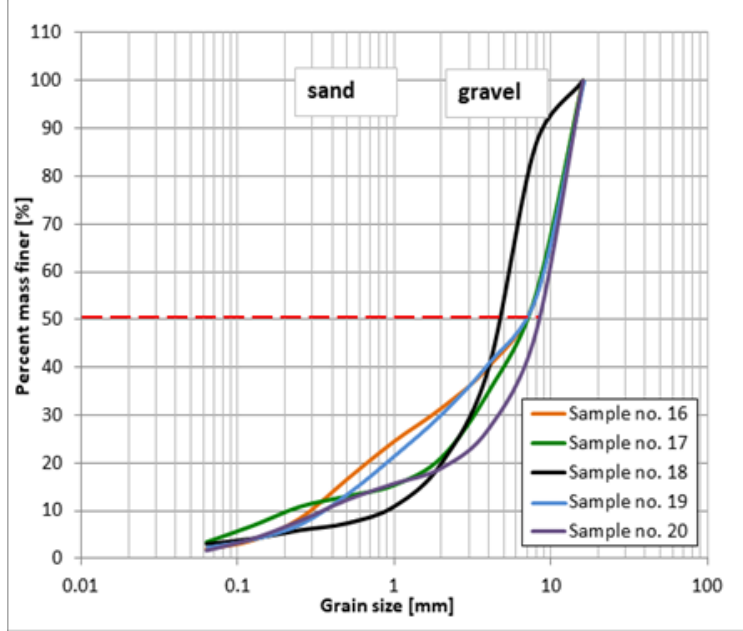

d)

Figure 3 Cumultative grain size distributions obtained by sieving from the 20 locations along upper Prahova River

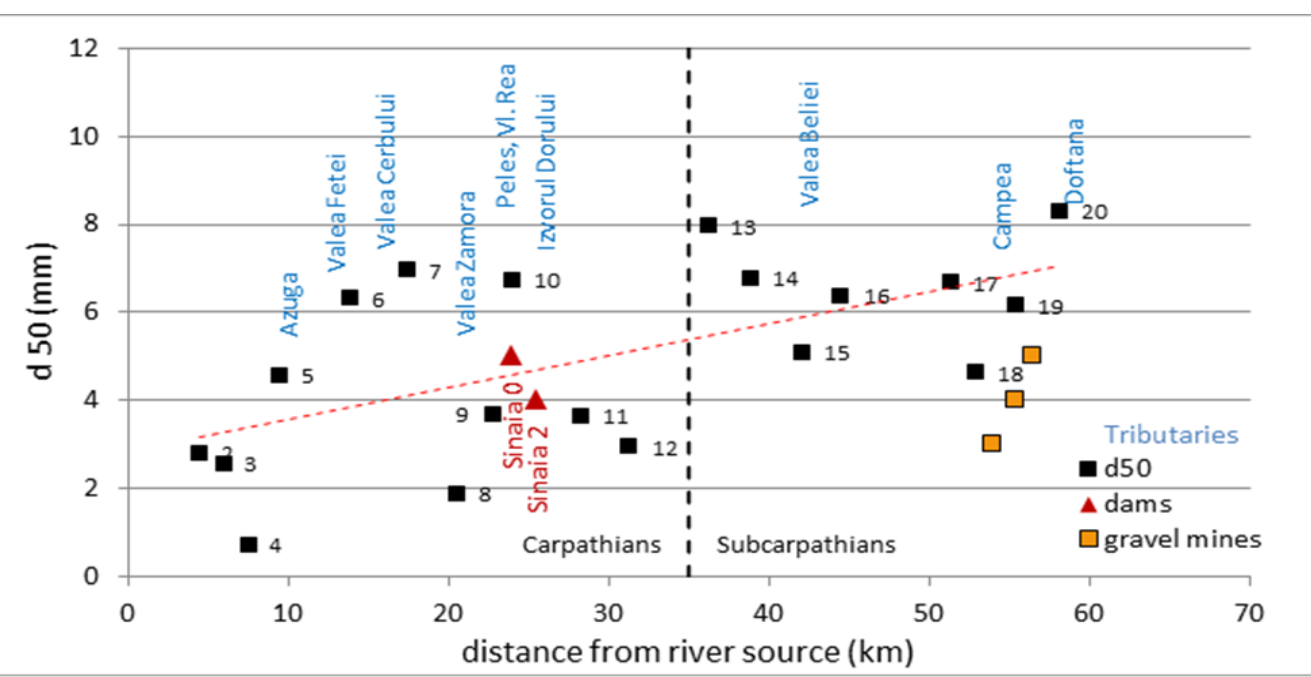

Figure 4 Longitudinal variation of $d_{50}$ from the subsurface sediment samples (upper Prahova River) 


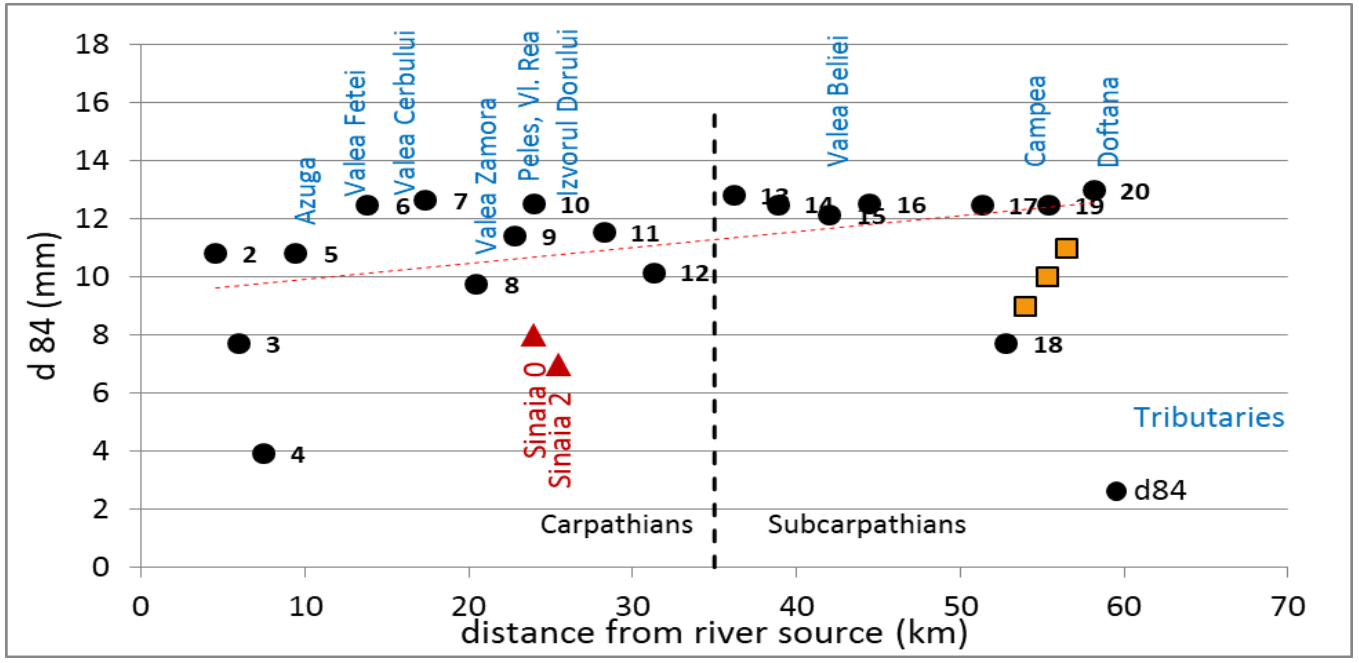

Figure 5 Longitudinal variation in size of $d_{84}$ from the subsurface sediment samples (upper Prahova River)

An example of lateral coarse sediment material inflow is the catastrophic flooding and debris flow event that occurred on 13.08.1999 (Sălăjan, 2017) in Bușteni-Poiana Țapului on Valea Cerbului River and on the smaller streams Valea Babei and Urlătoarea (all tributaries of Prahova River).

Another example of important coarse sediment supplied by the Valea Beliei tributary is the alluvial fan formed at the confluence with Prahova River due to frequent upstream slope sliding processes. Figures 6 a) and b) show the Valea Beliei confluence and the spillway filled up with sediments at the intake of the Lunca Cornului small hydropower plant, placed immediately downstream.

On the one hand, from Figure 4 and Figure 5, the local drop in diameters from sampling points 2 to 3 and 4 could be attributed to the small difference in altitude of the watershed and the lack of important tributaries down to the confluence with Azuga River. From location 5 to 6, Prahova River passes through the Genune narrow pass between the confluence with Azuga and Valea Fetei rivers, where the floodplain width narrows from $250 \mathrm{~m}$ to $70 \mathrm{~m}$ (Braşovanu, 2017), and therefore the channel velocity and sediment transport capacity increase.

The decrease in particle size from sampling point 11 with respect to 10 could be explained by their location downstream of the two dams Sinaia 0 and Sinaia 2 and by the absence of important tributaries.

On the other hand, the increase in grain size from location 13, situated at the exit of Posada Defile, may be caused by large velocities, shear stresses and therefore sediment transport capacity along this narrow stretch.

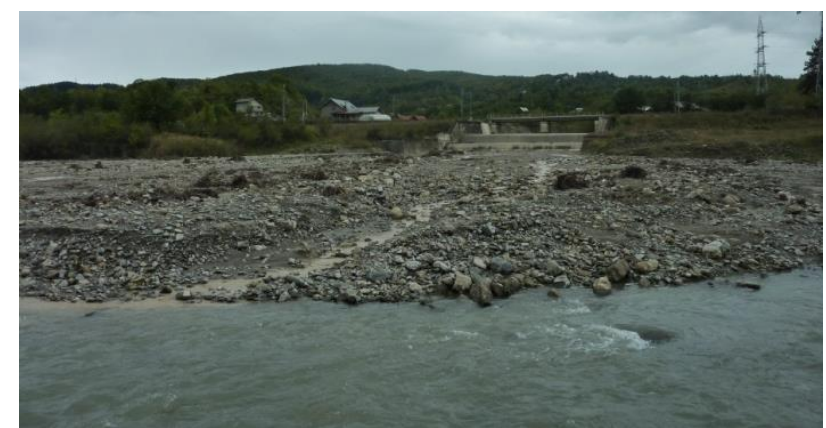

a)

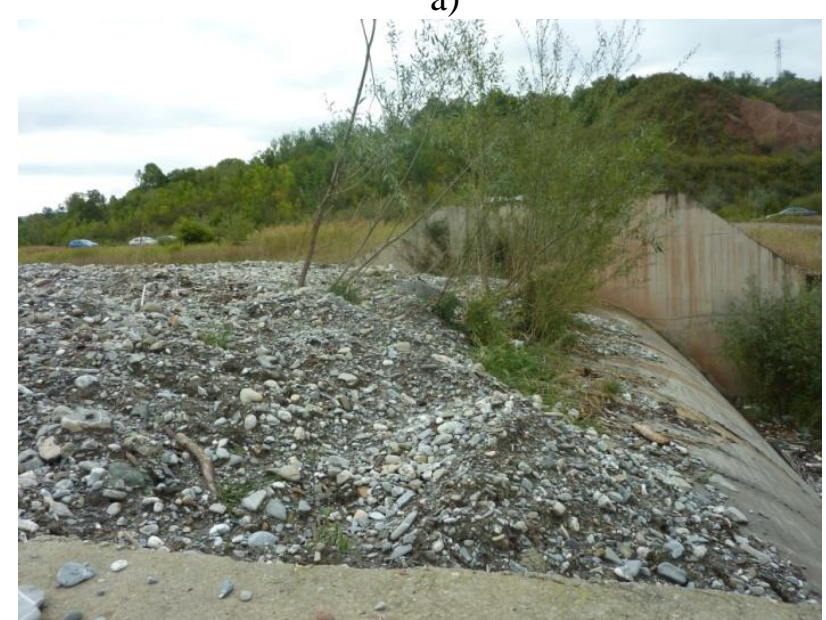

b)

Figure 6. a) Alluvial fan at the confluence with Valea. Beliei tributary; b) Sediments deposited up to the spillway crest of Lunca Cornului intake dam, downstream this confluence

The activity of the gravel mines situated at the downstream end of the study reach could also explain the important drop in grain size from locations 18 and selectively from 19 . 
Since significant incision was documented by Armaș (2012) and Brașovanu (2017), especially along the Subcarpathian reach of the Prahova River (where the river channel underwent major channel works), it is noteworthy to mention that several other researchers (Kondolf, 1997; Wyżga, 1993; Galia, 2013) argue about the existence of a possible connection between channel incision as a consequence of human impact and the coarsening of bed sediments in gravel-bed rivers.

\section{CONCLUSIONS}

The results of the grain size distribution analysis performed on samples taken from the subsurface layer of the exposed side or mid-channel bars from 20 locations along the upper Prahova River show a general downstream coarsening trend for both $d_{50}$ and $d_{84}$, which could have impact on stream biota.

In accordance with the explanations advanced by other authors for this unusual trend of gravel-bed rivers, the present paper proposes some hypotheses that match the conditions for the studied case.

From these, we mention: the high difference in altitude of the watershed, deforestation, coarse sediment input delivered by tributaries as a consequence of hillslope processes, incision caused by channel regulation and bank protection works, gravel mining, and presence of two dams.

Whereas hydrodynamic models may highlight the decrease of the onset of sediment transport and a selective transport of finer material along the potentially flow-depleted reaches when operating small run-of-river hydropower plants during low flow periods (Gogoașe Nistoran et al., 2018), a direct effect upon grain size variation in the subsurface, including high flow periods, still needs to be further investigated.

Further links with the variation of grain size from the surface layer, particle size frequency and percentage frequency distribution should be made. Also, given the complex influence of the interrelated control variables, additional systematic sampling is needed to better understand and explain the variation in time and space of the sediment grain size along the investigated reach.

\section{REFERENCES}

Armaș, I., Nistoran D. E., Braşovanu L. (2012), Catena, 100, pp. 83-99

Braşovanu, L. (2018), Morphodynamic study of Prahova River Channel along Carpathian and Subcarpathian reaches (in Romanian), $\mathrm{PhD}$ Thesis, University of Bucharest, Faculty of Geography, Bucharest, Romania

Braşovanu, L., Gogoaşe Nistoran D. E., Armaş I. (2018) Hydrological characteristics of upper Prahova River, GeoPatterns, vol. 3, issue 1, pp. 32-42

Brummer, C.J., Montgomery, D. R., (2003), Downstream coarsening in headwater channels, Water Resources Research, vol. 39, issue10, pp.1294-1307

Bunte, K., Abt, S. R., (2001), Sampling surface and subsurface particle-size distributions in wadable graveland cobble-bed streams for analyses in sediment transport, hydraulics, and streambed monitoring, Gen. Tech. Rep. RMRS-GTR-74. Fort Collins, CO: U.S. Department of Agriculture, Forest Service, Rocky Mountain Research Station

Dobre R. (2009), Pretabilitatea reliefului pentru căi de comunicație și transport în culoarul Prahovei (sectoarele montan și subcarpatic), Univ. of Bucharest, PhD Thesis

Dumitriu, D., Condurachi, D., Niculita, M. (2011), Downstream variation in particle size: A case study of the Trotus River, Eastern Carpathians (Romania), Analele Universitatii din Oradea - Seria Geografie, ISSN 1221 - 1273, E - ISSN 2065 -3409, no.2, pp. 222-232

Fergusson, R., , T., Wathen, S., Werritty, (1996) A. Field evidence for rapid downstream fining of river gravels through selective transport, Geology, vol. 24, issue 2, pp. 179-182

Galia, T., Škarpich, V., (2013), Coarse bed sediments in a headwater channel as indicators of fluvial processes and slope-channel coupling: a case study from the Carpathian Mountains (Czech Republic), Moravian Geographical Reports, vol. 21, issue 3, pp. 2-11

Gibson, S., Shelley, J., Cai, C., (2016), Downstream coarsening on the Missouri river, River Flow 2016, Iowa City, USA, July 11-16, pp. 2018-2023

Gogogase Nistoran, D., Ionescu, C.S., Livioara Brasovanu, L., Armas, I., Opris, I., Costinas, S., (2018), Modeling Hydrodynamic Changes Induced by Run-ofRiver Hydropower Plants along the Prahova River in Romania, Journal of Energy Engineering, vol 144, No. 2, pp. 1-11

Gogoase Nistoran, D.E., Braşovanu, L., Ionescu, C.S., Armaș, I., Cozma, A., (2019) Gravelometric image analysis of sediments (Prahova River, Romania), GeoPatterns, Vol. 4, pp. 26-32. 
Hedrick L. B., Anderson J. T., Welsh S. A., Lin L.-S., (2013), Sedimentation in Mountain Streams: A Review of Methods of Measurement, Natural Resources, vol. 4, 92-104

Ioana-Toroimac, G., (2014). La Dynamique Hydrogéomorphologique De La Rivière Prahova : Fonctionnement Actuel, Évolution Récente Et Conséquences Géographiques, University Publishing house, ISBN 978-606-28-0138-0.

Ioana-Toroimac, G., Zaharia L., Minea G., (2015), Using Pressure And Alteration Indicators To Assess Morphological Quality: Case Study of the Prahova River (Romania), Water, 7, 2971-2989; doi:10.3390/w7062971

Kondolf, G. M., (1997), Hungry water: effects of dams and gravel mining on river channels, Environmental Management, Vol. 21, p. 533-551

Leopold, L.B., Wolman, M.G., Miller, J.P. (1964), Fluvial Processes in Geomorphology, Freeman, San Francisco.

Parker, G., (2004), 1D sediment transport morphodynamics with applications to rivers and turbidity currents, e-book, http://hydrolab.illinois.edu /people/parkerg/morphodynamics_e-book.htm)

Rădoane, M., Rădoane, N., Ichim, I., Dumitriu, D., Miclaus, C., (2002), Granulometry of sediment deposits along several Carpathian rivers (In Romanian Granulometria depozitelor abie în lungul unor rauri carpatice), Revista Geografica, t. VIII, Bucuresti, pp. 70-77

Rădoane, M., Rădoane, N., Dumitriu, D., Cristea, I. (2006), Granulometry of Sediment Deposits from Prut River Channel between Orofteana and Galați (In
Romanian - Granulometria depozitelor abie ale raului Prut intre Orofteana si Galaţi), Revista de Geomorfologie a Universității din București, pp 53-64

Radoane Maria, Radoane N., Dumitriu D., Miclaus Crina (2008), Downstream variation in bed sediment size along the East Carpathian rivers: Evidence of the role of sediment sources. Earth. Surf. Process. Landforms, 33, 674-694;

Sălăjan L., (2017), Floods and flooding: from forecast to management, (in Romanian - Viiturile și inundațiile: de la prognoză la management, $\mathrm{PhD}$ Thesis, Bucharest)

Sear, D.A. 1992, Sediment transport processes in poolriffle sequences in a river experiencing hydropower regulation, In: Billi, P., Hey, R.E., Thorne, C.R. and Tacconi, P., eds., Dynamics of Gravel-bed Rivers, Chichester: John Wiley \& Sons, pp. 629-650

Schumm S. A., Stevens M. A. (1973), Abrasion in place: A mechanism for rounding and size reduction of coarse sediments in rivers. Geomorphology, 1, 37 - 40

Solari, L., Parker, G., (2000), The curious case of mobility reversal in sediment mixtures, ASCE Journal of Hydraulic Engineering, vol. 126, issue 3, pp. 185-197

Surian, N. (2002), Downstream variation in grain size along an Alpine river: analysis of controls and processes, Geomorphology, vol. 43, pp. 137-149

Veicat, D., Batalla, R. J., Garcia, C. (2006), Break-up and reestablishment of the armour layer in a large gravel-bed river below dams: The lower Ebro, Geomorphology, vol. 76, pp. 122-136

Wyżga, B., (1993), River response to channel regulation: Case study of the Baba River, Carpathians, Poland. Earth surface processes and landforms, Vol. 18, p. 541-556 